Siebren Miedema*

\title{
On Relevant Knowledge and Valorization in Religious and Worldview Education
}

https://doi.org/10.1515/zpt-2021-0002

"It is permissible to lump pure and applied scientists into the same scientific culture, but the gaps are wide."1

\begin{abstract}
Internationalization of academic research and international knowledge transfer can contribute to making religious and worldview educational practices relevant. Thus, international endearvors of academic research are also to be valued as well as national endeavors. However, neo-liberal perverse stimuli have had the upper hand in academic research policies since the 1980s. Thus research policy criteria and aims of academic research need to change in order to result in relevancy and valorization for pedagogical practices. Following a pragmatistic train of thought in philosophy of science can offer the possibility for a democratic approach which is truly oriented on the world's problems in which academic researchers, pedagogical practitioners, politicians and lay-persons can join forces.
\end{abstract}

Zusammenfassung: Internationalisierung wissenschaftlicher Forschung sowie internationaler Wissenstransfer können zur Relevanz von Bildungspraxen im Bereich von Religionen und Weltanschauungen beitragen. Daher ist neben der nationalen eine internationale Wertung wissenschaftlicher Forschung zu begrüßen. Allerdings haben neo-liberale perverse Impulse seit den 1980er Jahren in der Wissenschaftspolitik die Oberhand gewonnen. Daher müssen sich die Kriterien für die Forschungspolitik sowie die Ziele wissenschaftlicher Forschung ändern, um für pädagogische Praxisformen und deren Wertung relevant $\mathrm{zu}$ werden. Einem pragmatistischen Denkansatz in der Wissenschaftstheorie zu folgen bietet die Möglichkeit eines wirklich an Weltproblemen orientierten demokratischen Ansatzes, bei dem wissenschaftliche Forschung, pädagogische Praxis, Politik und Laien ihre Kräfte zusammenführen.

1 Charles Percy Snow, The Two Cultures and a Second Look. London/New York 1964, 31.

\footnotetext{
*Kontakt: Prof.Em. Dr. Siebren Miedema, Faculty of Behavioral and Movement Sciences \& Faculty of Religion and Theology, Vrije Universteit Amsterdam, The Netherlands, E-Mail: s.miedema@vu.nl
}

Ә Open Access. (C) 2021 Miedema, published by De Gruyter. (c) BY This work is licensed under the Creative Commons Attribution 4.0 International License. 
Keywords: knowledge transfer, valorization for religious and worldview education, internationalization, philosophy of science, pragmatistic view

Schlagworte: Wissenstransfer, Bewertung von Bildung im Bereich von Religionen und Weltanschauungen, Internationalisierung, Wissenschaftstheorie, Pragmatismus

\section{Introduction}

In this article I will reflect on the pros and cons of international knowledge transfer in religious and worldview education. This reflection is taking place within the framework of a continuing seminar of an international group of researchers in religious and worldview education brought together by Friedrich Schweitzer and Peter Schreiner that already met twice in Berlin, Germany in Autumn 2018 and 2019. In between these two sessions a joined manifesto was published in a variety of journals titled "International Knowledge Transfer in Religious Education: A Manifesto for Discussion"2.

From a philosophy of science perspective, my focus in the seminar is especially on the way researchers in academia are able to provide relevant knowledge and can contribute to fruitful valorization. In such conception of valorization the focus is on knowledge and insights that really matter for and have an intended impact on pedagogical and political practices, while at the same time contribute to improvement of both theoretical and empirical insights. This view on valorization is different from a conception of valorization as a by-product of academic research, because this focus is leading from the very outset of a research project.

To be very clear from the outset and as a matter of critical self-reflection: internationalization has been very important in my own academic career since I started as a tenured assistant professor for teaching and research at Leiden University in 1981. As part of that appointment I was at the same time working on my doctoral

2 Friedrich Schweitzer/Peter Schreiner, International knowledge transfer in religious education: universal validity or regional practices? Backgrounds, considerations and open questions concerning a new debate. In: British Journal of Religious Education 42 (2020), 381-390. Friedrich Schweitzer/Peter Schreiner, International knowledge transfer in religious education - a manifesto for discussion. In: Religious Education 115 (2020), 10-14 (also printed in this journal: Zeitschrift für Pädagogik und Theologie 71 [2019], 90-95). Friedrich Schweitzer, Letter to the editors concerning international knowledge transfer in religious education. In: Journal of Beliefs and Values 41 (2020), 1-4. Friedrich Schweitzer, International knowledge transfer in religious education? The example of Germany and South Africa as test case. In: HTS Teologiese Studies/Theological Studies 75 (2019), http://www.hts.org.za, 1-7. 
dissertation focusing from a philosophy of education as well as a philosophy of science point of view on the theory-practice debate in the pedagogical sciences. Writing a dissertation was done next to all other duties of an assistant professor: lecturing, administrative work in the department and/or faculty, and representing the university in a national consortium of theoretical and historical pedagogues. The change to the current $\mathrm{PhD}$-system, that is just working during three or four years fulltime on the dissertation, had just started around 1983.

My dissertation was - very intentional - not as usual in the pedagogical sciences in the Netherlands a monograph, but a collection of coherently connected and published articles and chapters in Dutch with an unpublished lengthy introductory chapter and at the end an unpublished discussion chapter. The result was a book of 329 pages in Dutch published with an academically well-respected publisher in Belgium and the Netherlands ${ }^{3}$. A shortened version of a chapter on Erich Weniger was already published in German in the international journal Paedagogica Historica in $1983^{4}$, and another part in English was going to be published in the Australian journal Curriculum Perspectives ${ }^{5}$ a month after the defense in September 1986. Two articles based on the dissertation project were already accepted in 1986 and published in 1987 respectively in German in Pädagogische Rundschau ${ }^{6}$ and in English in Phenomenology + Pedagogy ${ }^{7}$.

Important for my international orientation was the young and very ambitious research group in Leiden that I joined in 1981 and that was led by a young and bright full professor of just 29 years old. Publishing in German and English next to Dutch, as well as attending international conferences and presenting papers there was quite common in that research group since the early 1980 s.

Besides, at the national level the Ministry of Education launched in 1983 the plan to concentrate high quality research in so-called 'centers of excellence', that is centers characterized by intense research exchange with foreign researchers and strongly focusing on international publications. From 1978 on Leiden University together with the Catholic University Nijmegen were taking part in an exper-

3 Siebren Miedema, Kennen en handelen. Bijdragen aan het theorie-praktijk-debat in de opvoedingswetenschappen. Leuven/Amersfoort (Acco) 1986.

4 Fons Beugelsdijk/Siebren Miedema, Geisteswissenschaftliche und kritische Padägogik. Über Kontinuität und Diskontinuität im Werk Erich Wenigers. In: Paedagogica Historica. International Journal of the History of Education 23 (1983), 283-289.

5 Siebren Miedema/Els Heimans, The Marburg Elementary School Project: the Weal and Woe of an Action Research Program. In: Curriculum Inquiry 6 (1986), 47-49.

6 Siebren Miedema, Pädagogik an der Nahtstelle zwischen System und Lebenswelt. In: Pädagogische Rundschau 41 (1987), 747-757.

7 Siebren Miedema, The Theory-Practice Relation in Critical Pedagogy. In: Phenomenology + Pedagogy 5 (1987), 221-229. 
iment that resulted in an intended research policy to establish such centers of excellence. So, the institutional research culture at Leiden University was already since 1978 characterized by a strong emphasis on the importance of international cooperation and international publications.

From a minor in post-Kuhnian sociology of science ${ }^{8}$, that I took during my master in philosophy of science, I also knew that the strength of a research group in terms of clear focus, internal (research group) and external (national and international) collaboration is fertile soil for individual researchers too. It was also quite soon very clear to me that my teaching should be very good to excellent, however, for me, a tenured and progressive academic career performance in research was of much greater importance. Research 'output' was at that time, and sometimes still is, the most important parameter on the way to a higher ranked professorship in academia.

\section{Two souls were living in my chest}

However, two souls were at the same time living in my chest, because the theme of my dissertation research was the theory-practice debate in the pedagogical sciences. I took a critical-emancipatory stance here, heavily inspired by the work of Wolfgang Klafki, his philosophy of educational stance in terms of the aims of education and his view on pedagogical research. Crucial for academic research should be that on the basis of theoretical and empirical outcomes obtained with action research methods, pedagogical practitioners are able to gain greater self-insight and are provided with more adequate analyses of and tools for their situation. That will sustain them in making the aim of pedagogy realizable in terms of stimulating at the side of children and young people self-reliance, self-determination, self-responsibility at the individual level, as well as sociability and solidarity at the social level. Such a critique can be formed by research into the economic, social, and political presuppositions, limits, dependences, and implications of pedagogical processes.

But, according to Klafki, the knife of the critique cuts two ways. Pedagogical theory and research must also be prepared to direct the processes of enlightenment and critique at itself, because pedagogical theory was and still is so often

8 Derek John De Solla Price, Little Science, Big Science. New York (Columbia University Press) 1963. Michael John Mulkay, The Social Process of Innovation. London/Basingstoke (Macmillan) 1972. Diana Crane, Invisible Colleges. Diffusion of Knowledge in Scientific Communities. Chicago/ London (University of Chicago Press) 1972. 
blind to the economic, social, and political dimensions of as well as the tremendous impact these dimensions have on education. Pedagogical research and theory on the one hand and pedagogical practices on the other are dependent on each other in a reciprocal relationship. Cooperation between pedagogical theorists and practitioners is of utmost importance?

Following this train of thought, I also published articles in professional educational journals and articles in national newspapers about burning pedagogical issues in the period that I was working on my dissertation. It was already my contention that academic pedagogues should contribute to the broad pedagogical-cultural debate by being present with a diversity of written and/or oral contributions. In my view, only focusing on international publications is a threat for fruitful relationships between academic pedagogues and pedagogical practitioners ${ }^{10}$. Later in my career, as head of a department of philosophy and history of education, and as dean of a faculty of psychology and education, I have always invited research leaders, and given the freedom to research groups to choose as groups for a variety of publication patterns and of course also for underpinning such a policy with a comprehensible and clear mission and vision on their research.

Since the mid-1980s there was an ongoing reinforcement on internationalization with the following practices: extreme emphasis on international publications and international exchange; assessment committees nearly exclusively staffed with scholars from abroad, with self-reports in English, only five core publications in English, and ten professional publications in Dutch that were, however, not taken into account in the assessment and could not be read by the non-native Dutch members; international publications had become the far most important criterion for a successful academic career. The 1995 assessment committee for pedagogical and educational sciences wrote in its conclusions on publishing and publication policy “( $\mathrm{t}$ )hough quite a number of publications in Dutch refereed journals [...] and in handbooks as well are important for the research of practitioners, the faculty should encourage the researchers to write publications and theses in English, because publishing in the international press means participation in the advancement of science as an international effort"11.

9 See in extenso on this issue Siebren Miedema, Strengthening the links between academia, lifeworld and politics in religious and worldview education. In: Friedrich Schweitzer/Peter Schreiner (Eds.), International Knowledge Transfer in Religious Education. Münster/New York (Waxmann) 2021, 229-242.

10 Siebren Miedema, Over publiceren en het pedagogisch debat. In: Vernieuwing. Tijdschrift voor Onderwijs en Opvoeding 47 (1988), 3-4.

11 VSNU, Pedagogical and Educational Sciences. Past Performance and Future Prospects. Utrecht 1995, 11. 
My senior colleague from Nijmegen, Wouter van Haaften, shared my concerns in respect to the reduced focus in research policies and practices. So, we decided to invite ten full professors in diverse subdisciplines of education and pedagogy in the Netherlands and Flanders (Belgium) to reflect on the pros and cons of internationalization. One of the issues was also the pressure put on the use of English as well as the disregard of using Dutch as a medium for academic communication. In our view, this could seriously impact the interrelationship of academia and other societal practices, and might even result in a complete withdrawal of academics from the necessary broad national pedagogical-cultural debates.

We gained the following insights: quite some subdisciplines only wanted to focus on international publications (it was said that this was their main and most important forum); even in special education some participants preferred international theoretical and empirical work over direct or indirect improvement of Dutch special educational practices; the work of colleagues who definitely wanted to contribute to care and therapy in the Netherlands was less valued and seen as of minor academic quality; quite some Dutch academic journals had hard times or already stopped, because less articles were submitted and it was very difficult to find book reviewers. Thus, we became aware of the dangers of exclusively focusing on internationalization and at international fora at the detriment of the respective national context with its own debates, problems and challenges ${ }^{12}$.

\section{Critical reflection is needed}

Moving to the Vrije Universiteit Amsterdam in 1993, my main area of research became religious and worldview education. It was possible and necessary to establish immediately very strong links with national intermediate organizations in the field as well as with principals of elementary schools within the set-up of in-service training and with leaders of secondary and higher education. I could, together with my co-workers, even better practice than before a variety of publication patterns.

International cooperation and research were very important as well. We participated for instance in the European REDCo-project that ran from 2006 to 2009 and continued as an extended network from 2009 till 2012. It was the first major inter-European research project on religion and education funded by the Euro-

12 Siebren Miedema/Wouter van Haaften (Eds.), Pedagogiek over de grens. Over de internationalisering van de pedagogiek. Utrecht (SWP) 1998. 
pean Commission with an amount of 1,5 million Euro. We published numerous academic articles in established academic journals and also edited volumes in English based on the many milestones and deliverables which we had to produce in time during these three years. We also organized events in the eight participating countries where we invited representatives from academia, politics and governments and made it to Brussels and Strasbourg too. Some books were also written in national languages other than English ${ }^{13}$.

Academically speaking, comparing cross-national theoretical, historical and qualitative as well as quantitative empirical findings have the benefit of offering at least a hermeneutical framework for more adequate insights in national contexts, debates and policies. Researchers may become alert on similarities and differences, thus providing more adequate insights into, in our case, the theories, practices and policies characteristic of the Dutch context. International comparative research might function as a hermeneutics of understanding the own and the other context better. That is really a positive attainment, because it may strengthen policy-making and decision-making in respect to pedagogical approaches in practice.

However, the irritating question I cannot get rid of was and still is at hindsight in respect to the REDCo-project whether the joint international research projects had enough to offer for practices and politics in the own countries of origin. Did our work really have concrete impact on political and governmental decision-making and on educational practices and policies in regard to religious and worldview education from the perspective of valorization? I am really hesitant to give a clear-cut positive answer to this question that continues to rankle me. Besides, a lot of data have not been used, because there was no time left to work on that collectively, and every participating research group was already busy in the final stage of the project to try and get new research grants accepted - with an eye on getting money for new, unfortunately mostly just temporary, appointments of the participating junior staff members in the REDCo-project as well.

13 Robert Jackson/Siebren Miedema/Wolfram Weisse/Jean-Paul Willaime (Eds.), Religion and Education in Europe. Developments, Contexts and Debates. Münster/New York/München/Berlin (Waxmann) 2007. Ina ter Avest/Gerdien Bertram-Troost (Eds.), Geloven in samen leven. Amsterdam (Gopher/Science Guide) 2009. 


\section{Where do we stand, where to go?}

In the current situation it is, in my view, absolutely necessary to be again and again critical and reflective concerning the research policies and practices in academia. What is the state of the art? Academic research practices have become more and more a reality in its own right, market driven by the ideology of the New Public Management wherein, for example, finalized dissertations are primarily seen as an important budgetary parameter instead of first and foremost evaluated as a relevant contribution to pedagogical practices and strengthening the theoretical, empirical and real underpinning of these practices or to improvement of theory. Quite often, research has greatly become a practice in its own right, driven by perverse stimuli focusing on highly cited journal publications resulting among other things in high Hirsch-scores for individual researchers. Scores that are mostly only important for these individual academics to acquire accepted grant proposals and resulting in higher ranked and better paid academic positions ${ }^{14}$. These practices have not only become business-as-usual in the faculties of the 'hard' sciences, but also in faculties of social sciences and humanities, including faculties of religion and theology. One of the consequences of the current situation is also that real educational practices have often become too much of a theoretical or virtual entity instead of a real empirical context seriously taken into account in the academic practices of research. We definitely need to stay away from the above mentioned perverse neo-liberal and market-oriented practices which sometimes have been adequately characterized as forms of 'cognitive capitalism'.

In terms of internationalization of empirical research in education, PSA is also an interesting case. While focusing on 'competence' there is still the danger that educational systems become hegemonic out of a fear of being left behind and transform themselves in a system that counts while only dealing with particular outcomes and with a strong grip on schools "through a combination of curriculum prescription, testing, inspection, measurement, and league tables”15.

14 Siebren Miedema, Bildung in Zeiten des Wandels. Konturen und Herausforderungen. In: Zeitschrift für Pädagogik und Theologie 69 (2017), 82-91. Siebren Miedema, We Need Religious Educators as Public Intellectuals. A Manifesto. In: Manfred Pirner/Johannes Lähnemann/Werner Hausmann/Susanne Schwarz (Eds.), Public Theology. Perspectives on Religion and Education. New York/London (Routledge) 2019, 250-255.

15 Gert Biesta, The Beautiful Risk of Education. Boulder/London (Paradigm) 2014, 121. See also at length on this issue Gert Biesta, Good Education in an Age of Measurement. Ethics, Politics, Democracy. Boulder/London (Paradigm) 2010 and Gert Biesta/Siebren Miedema, Instruction or pedagogy? The need for a transformative conception of education. In: Teaching and Teacher Education 18 (2002), 173-181. 
However, there are also positive developments for instance embodied in the Erasmus+ projects financed by the European Union where theory and practice strongly come together. One such project is the international READY project on Religious Education and Diversity of students, teachers, teacher students and teacher educators in Religious Education ${ }^{16}$.

Which direction should we go? Elsewhere ${ }^{17}$, I have made a plea to strengthen the links between academia, lifeworld and politics in religious and worldview education. I called on to revitalize a critical-emancipatory theory-practice relationship with as its core the reciprocity of the two sides of this relationship. Instead of a decisionistic or a technocratic model of the relation between science, politics and practice we should follow, in Habermas' terms, a pragmatistic model, because it "is necessarily related to democracy" 18 , with no strict separation of the role and function of the scientist and the politician. The relationship of science and politics should be one of critical reciprocity between scientists and politicians. The practice of science is also part of democratic society and is focusing on it together with politicians and practitioners in terms of public debate, communication, responsibility, and value-ladenness. This includes the public debate on values, control, re-direction of research topics and problems. "The relation of the sciences to public opinion is constitutive for the scientization of politics"19.

Such a pragmatistic view sustains critique on certain dangers of self-centeredness and only internally driven academic practices. That's why I am also in favor of an Open Science approach. For such an approach it is key that all relevant societal partners work closely together from the outset on what is seen by all stakeholders as a relevant societal problem. The problem scale may be local, regional, national, international, or global, and should be defined by the nature of the problem-in-context. The co-operation and collaboration of relevant partners and stakeholders with respect to problems at hand should be practiced in both the context of discovery, the context of justification or legitimation as well as in the context of use or application. There are no strict dividing lines between these three contexts ${ }^{20}$.

16 Peter Schreiner (Ed.), Are you READY? Diversity and Religious Education across Europe - The Story of the READY Project. Münster/New York (Waxmann) 2018.

17 Siebren Miedema, Strengthening the links between academia, lifeworld and politics in religious and worldview education. In: Friedrich Schweitzer/Peter Schreiner (Eds.), International Knowledge Transfer in Religious Education. Münster/New York (Waxmann) 2021, 229-242.

18 Jürgen Habermas, Toward a Rational Society. London (Heinemann) 1971, 67.

19 Ibid., 69.

20 See in extenso dealing with the philosophy of science discussion on these matters Miedema, Strengthening the links between academia, lifeworld and politics. 
A pragmatistic view also takes into account the fact that from an internal academic point of view it should be clear that academic research is not the act and performance of an individual researcher, but, as Thomas Kuhn already in the 1970s convincingly has shown, a social practice and the work of a research team ${ }^{21}$. National and transnational research programs should be taken as the entity of evaluation or assessment instead of individual researchers. The focus must be on the problems to be solved and the questions that need to be answered.

From a pragmatistic point of view, and with an eye on the ontological, epistemological, anthropological and normative intertwinement of academia, lifeworld practices and politics, valorization of outcomes, results and insights are no longer seen as a by-product of academic practices, as a kind of surplus. In such a case we take it only into consideration if we have some time left for these extra activities. Valorization, however, should be characterized as a core constituent of academic work and research from the outset.

In the practices of academic research on worldview and religion, we should emphasize the importance of both quality (that is reliability and comprehensibility) and relevancy (in terms of validity and transferability). All research outcomes need interpretation from within a hermeneutical-critical horizon of understanding. For quantitative research this requires repeatability ('replicability') of research results, and for both qualitative and quantitative results intersubjective comprehensibility ('reliability'). Research results are not mirroring as true statements an objective outside reality but have the power of what Dewey has coined as warranted assertibility. "The use of the term that designates a potentiality rather than an actuality involves recognition that all special conclusions of special inquiries are parts of an enterprise that is continually renewed, or is a going concern"22. Statements ('facts') are brought in as chains of argumentation in the democratic negotiation between all partners involved. Partners, who are all aware of the normative ladenness of the subject matter at stake as well. The validity of the results is gained in the transactional relationships with all partners involved ('facticity'), where the important criterion is whether it really does matter what we have scrutinized for pedagogical practices dealing with religious and worldview education and for politics.

From such a pragmatistic perspective, I am still in favor of comparative national and cross-national theoretical, historical and quantitative as well as qualitative research. As I stated above, such research has the benefit of offering

21 Thomas Kuhn, The Structure of Scientific Revolutions. Chicago/London (University of Chicago Press) 1970.

22 John Dewey, Logic: The Theory of Inquiry. New York (Holt, Rinehart \& Winston) 1982, 9. 
at least a hermeneutical framework for more adequate insights in international as well as national contexts, debates and policies. Thus, international knowledge transfer can strengthen the hermeneutical potentialities with an eye on transferability of outcomes also with a focus on the contextual and the particular.

\section{Epilogue}

This contribution is intended to strengthen the underpinning of a view on practices of focusing on relevant knowledge and to stimulate this view as well as the valorization in religious and worldview education both nationally as well as internationally. I have pointed to hindering policies and practices in academia and beyond that we definitively need to overcome following this path. I am optimistic that this will happen, because we can notice positive developments in this direction across Europe and in the USA where the contribution of academic research to the human good is more seriously taken as the aim of research and the concepts of 'Open Science' and 'citizen science' are flourishing more and more ${ }^{23}$. The way researchers have reacted on the COVID-19 pandemic is, in my opinion, exemplary for this new constellation, because so many researchers from different academic disciples have joined forces in fighting this virus for the well-being of humankind. That is a hopeful sign!

23 See Miedema, Strengthening the links between academia, lifeworld and politics. 